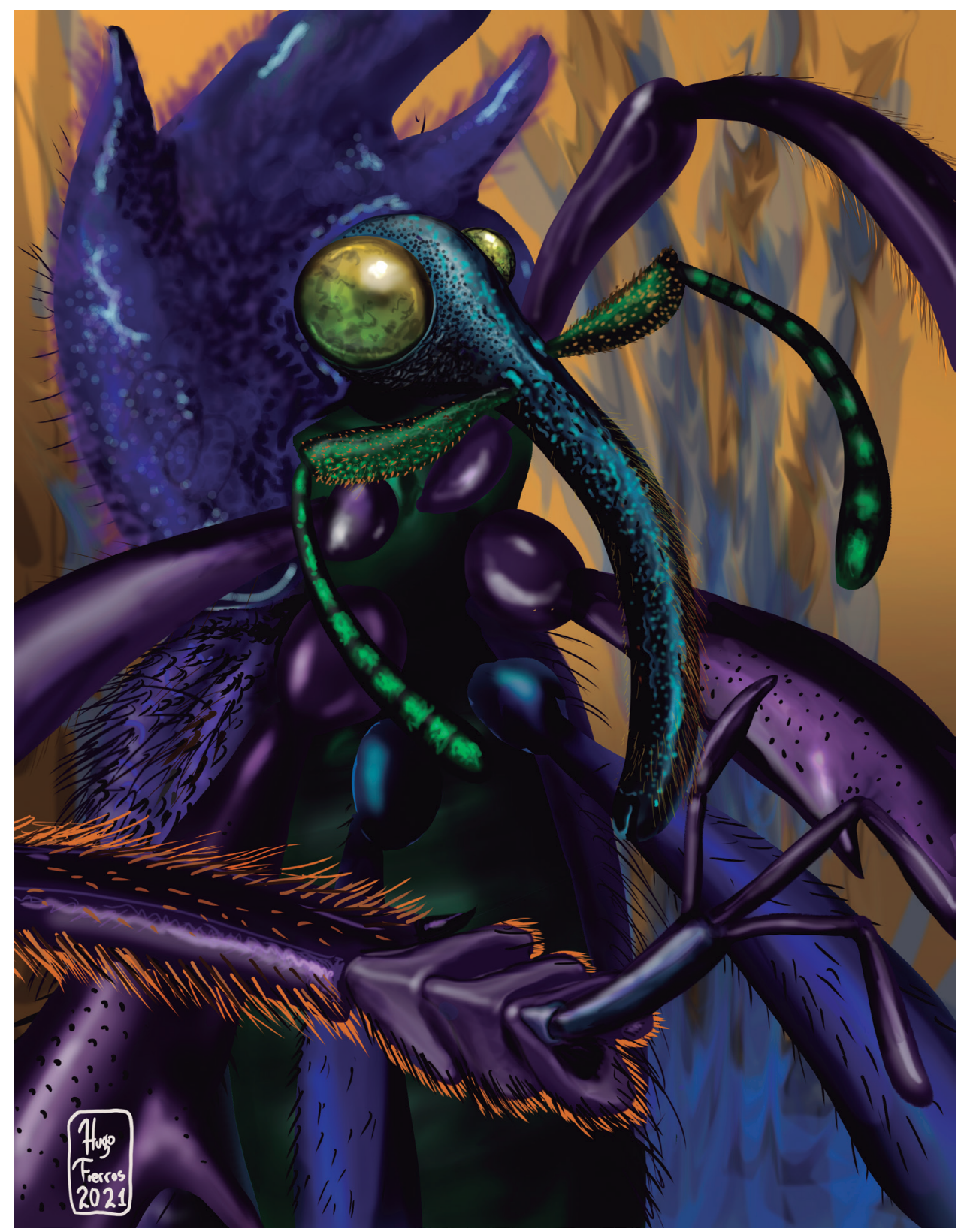

Dugesiana, Año 28, No. 2, (julio-diciembre, segundo semestre de 2021), es una publicación semestral, editada por la Universidad de Guadalajara, a través del Centro de Estudios en Zoología, por el Centro Universitario de Ciencias Biológicas y Agropecuarias. Camino Ramón Padilla Sánchez \# 2100, Nextipac, Zapopan, Jalisco, Tel. 37771150 ext. 33218, http://148.202.248.171/dugesiana/index.php/DUG/index, glenusmx@gmail.com. Editor responsable: José Luis Navarrete-Heredia. Reserva de Derechos al Uso Exclusivo 04-2009-062310115100-203, ISSN: 2007-9133, otorgados por el Instituto Nacional del Derecho de Autor. Responsable de la última actualización de este número: José Luis Navarrete-Heredia, Editor y Ana Laura González-Hernández, Asistente Editorial. Fecha de la última modificación 1 de julio de 2021, con un tiraje de un ejemplar.

Las opiniones expresadas por los autores no necesariamente reflejan la postura del editor de la publicación.

Queda estrictamente prohibida la reproducción total o parcial de los contenidos e imágenes de la publicación sin previa autorización de la Universidad de Guadalajara. 


\title{
New taxa of neotropical Lygaeinae (Hemiptera: Heteroptera: Lygaeoidea: Lygaeidae)
}

\section{Nuevos taxones de Lygaeinae neotropicales (Hemiptera: Heteroptera: Lygaeoidea: Lygaeidae)}

\section{Harry Brailovsky}

Departamento de Zoología, Instituto de Biología, Universidad Nacional Autónoma de México, Apdo. Postal No. 70153, México 04510, Ciudad de México: e-mail: coreidae@ib.unam.mx. ORCID: https://orcid.org/ 0000-0001$7456-5678$

\begin{abstract}
The new genus, Zygocellus gen. nov., with the single species Z. saphisus sp. nov from Bolivia, is described. Additionally, three new species in the genus Ochrimnus are described: Ochrimnus (Aglaochrimnus) nigrosteolaris sp. nov. from Venezuela, O. (Aglaochrimnus) rostratum sp. nov. from Brazil, and O. (Orthochrimnus) naevillus sp. nov. from Colombia. Also, the new species Zygochrimnus morronesus sp. nov. is described from Argentina. Photographs of the dorsal habitus of each species, and the parameres of some species are included. A discussion of their relationships with related species, in their respective genera, is provided.

Key words: Hemiptera, Heteroptera, Lygaeidae, Lygaeinae, new genus, new species, Neotropical Region.

\section{RESUMEN}

Un nuevo género Zygocellus gen. nov., con una sola especie Z. saphisus sp. nov de Bolivia es descrita. Adicionalmente, tres nuevas especies del género Ochrimnus son descritas: Ochrimnus (Aglaochrimnus) nigrosteolaris sp. nov. de Venezuela, O. (Aglaochrimnus) rostratum sp. nov. de Brazil, y O. (Orthochrimnus) naevillus sp. nov. de Colombia. Ademas, una nueva especie Zygochrimnus morronesus sp. nov, es descrita de Argentina. Fotografías en vista dorsal de cada especie, y los parámeros de algunas de ellas son incluídas. Se discuten las relaciones que guardan las especies, en sus respectivos géneros.
\end{abstract}

Palabras clave: Hemiptera, Heteroptera, Lygaeidae, Lygaeinae, Nuevo género, nuevas especies, Región Neotropical.

The lygaeid subfamily Lygaeinae is represented in the Western Hemisphere by 24 genera, 7 subgenera and 216 species (A. Slater 1992, Henry et al. 2015, Dellapé and Henry 2020). Members of the subfamily are usually moderate sized to very large lygaeids. Most of the species are recognizable by their contrasting red and black or orange and black coloration; all abdominal spiracles dorsal; hemelytra impunctate; membrane of forewing usually with a distinct basal cell; hind wing with hamus and subcostal vein; and with sutures of the abdominal venter straight or nearly so, and all reaching lateral margins of abdomen (A. Slater \& Baranowski 2001, Baranowski \& A. Slater 2005, Cervantes-Peredo \& Brailovsky 2014, Brailovsky 2018).

The present paper adds one new genus and five new species from Argentina, Bolivia, Brazil, Colombia and Venezuela, and each species is described and photographed.

\section{MATERIALS AND METHODS}

External structures were studied with a stereoscopic microscope (model Zeiss Stereo Discovery). Pictures were taken with a Nikon D200 camera. The following abbreviations are used for the institutions cited in this paper:
BMNH Natural History Museum, London, England;

CMNH Carnegie Museum of Natural History, Pittsburgh, PA, USA;

IZAV Instituto de Zoología Agrícola, Maracay, Venezuela; UCRC Entomological Teaching and Research Collection, University of California, Riverside California, USA;

UNAM Colección Entomológica, Instituto de Biología, Universidad Nacional Autónoma de México, México; UNDC Universidad Nacional de Colombia, Instituto de Ciencias Naturales, Bogotá, Colombia.

\section{TAXONOMY}

Ochrimnus (Orthochrimnus) naevillus sp. nov.

Figure 5

http://zoobank.org/4A187973-6AD9-48C1-92D16520AF3A9556

Type locality. Colombia, Cundinamarca.

Type material. Holotype $\hat{\sigma}$, COLOMBIA: Cundinamarca. Chipinque, Vereda Las Fruticas, 3570 m, 4³44’N7095' W, 9-12.x.2014, C. Dumar (UNDC).

Description. Male (holotype). Dorsal coloration. Head black, with a pale yellowish spot at vertex; antennal segments I-III pale castaneous, IV yellow with apex pale castaneous; antenniferous tubercle pale castaneous; eyes 
and ocelli dark red; pronotum black, with a short triangular yellowish mark on middle third of posterior margin and reaching calli; scutellum black with apex yellow; clavus black, with anterior angle pale yellowish brown; corium black with anterior third, apical margin and veins yellow; basal half of costal margin of corium yellow, apical half black; hemelytral membrane black, apical border slightly greyish;connexival segments black; dorsal abdominal segments III-V pale orange, VI with anterior half pale orange and posterior half black, segment VII black.

Ventral coloration. Head and rostral segments I-IV black; buccula yellow; thorax black with acetabulae, ostiolar peritreme, anterior margin of propleuron, posterior border of meso-, and metapleura, and upper margin of metapleuron yellow; legs with coxae reddish brown; trochanters yellow; femora reddish brown with apical third dark yellow; tibiae and tarsi pale castaneous orange; abdominal sterna and genital capsule black.

Structure. Head moderately declivent; ocelli scarcely raised above surface; antennal segment I surpassing tylus about $1 / 3$ its length; buccula moderately raised; rostrum reaching posterior border of mesocoxae; pronotum subquadrate, wider than long, with four transverse impressions behind each callus; scutellum wider than long; stem and arms equally broad; apex subacute; hemelytra submacropterous, reaching middle third of abdominal segment VI; claval and corial veins slightly raised.

Vestiture. Dorsally and ventrally with short, fine, silvery, decumbent setae.

Measurements. Male holotype. Body length $3.50 \mathrm{~mm}$. Head length $0.61 \mathrm{~mm}$; width across eyes $0.92 \mathrm{~mm}$; interocular distance $0.50 \mathrm{~mm}$; interocellar distance $0.38 \mathrm{~mm}$; preocular distance $0.40 \mathrm{~mm}$; length antennal segments: I, $0.24 \mathrm{~mm}$, II, $0.54 \mathrm{~mm}$, III, $0.48 \mathrm{~mm}$, IV, $0.64 \mathrm{~mm}$. Pronotum length $0.66 \mathrm{~mm}$; width across humeral angles $1.04 \mathrm{~mm}$. Scutellum length $0.36 \mathrm{~mm}$, width $0.44 \mathrm{~mm}$.

Female. Unknown.

Differential diagnosis. Ochrimnus (Orthochrimnus) naevillus sp. nov., like Ochrimnus (Orthochrimnus) testatus Brailovsky, 1982, are the only species in the genus with subquadrate pronotum and submacropterus hemelytra. However, the new species can be distinguished from the latter in having the body shorter than $3.55 \mathrm{~mm}$; head black, with a pale yellow spot on vertex; pronotum black, with a short triangular yellowish mark on the middle third, just reaching the calli; and hemelytral membrane reaching middle third of abdominal segment VI. In $O$. (O.) testatus the body is longer than $4.60 \mathrm{~mm}$; the head is dorsally dark ochre with tylus and vertex black and with a yellowish discoidal spot on vertex; pronotal disk, brown with a dark-ochre, narrow, longitudinal stripe extending along the pronotum, through the middle third of pronotum; and the hemelytral membrane not surpassing abdominal segment $\mathrm{V}$.

Etymology. From the Latin, naevus (mark), and the diminutive suffix illus, in reference to the small yellowish triangular spot on the posterior lobe of the pronotal disk.
Distribution. Colombia: Cundinamarca.

\section{Ochrimnus (Aglaochrimnus) nigrosteolaris sp. nov.}

Figures 3, 7-8

http://zoobank.org/C3C26DA1-A9A4-4C36-A4CF6DB1323E82AD

Type locality. Venezuela, Mérida.

Type material. Holotype $\widehat{\partial}$, VENEZUELA: Mérida, km 20 Mérida El Morro, 2400 m, 20.xi.1992, col. C. Bordón (UNAM). PARATYPES: 4 $ぇ, 2$ 2 , , VENEZUELA: Mérida, Valle Grande, 11.v.1972, J. B. Terán \& B. R. Cásares (IZAV). 3 ๙ึَ, 1 +, VENEZUELA: Mérida, El Valle, 2400 m, 22.v.1983, C. Bordón (UNAM). 2 đô, VENEZUELA: Mérida, Carbonera, 2000 m, 22-27.vi.1968, J. y B. Bechyne (IZAV). 1 q, VENEZUELA: Mérida, La Mucuy, 19.vi.1975, M. Rojas (UNAM). 1 \%, VENEZUELA: Mérida, La Azulita, 2000 m, 2.x.1969, J. y B. Bechyne (UNAM).

Description. Male (holotype). Dorsal coloration. Head black with pale yellow discoidal spot on vertex; antennal segments I-IV dark reddish brown to black; ocelli shiny red; eyes dark red; pronotum black; anterior and posterior margins yellow; anterolateral margins black or very narrowly and indistinctly yellow on the anterior third; scutellum black with apex yellow; clavus and corium black with claval commissure, and costal and apical margins yellow; costal margins of corium yellow, narrowing apically; hemelytral membrane black with narrow white margin; connexival segments black with upper border yellow; dorsal abdominal segments III-VI shiny orange, VII black.

Ventral coloration. Head and rostral segments I-IV black; buccula white; prosternum black with a broad white anterior margin; meso-, and metasterna black; propleuron black with a broad white posterior margin; meso-, and metapleuron with narrow white to dark orange posterior margins; ostiolar peritreme black; pro-, meso-, and meta-acetabulae white; legs black to dark reddish brown; abdominal sterna III-VI shiny orange with black irregular and diffuse longitudinal stripe along midline and at lateral margins; posterior border of sternites IV-VI black; pleural abdominal borders dark yellow; sternite VII black with upper border yellow; genital capsule black.

Structure. Head moderately declivent; vertex convex; ocelli raised above surface; antennal segment I surpassing tylus by about $1 / 3$ its length; buccula moderately raised; rostrum reaching posterior border of metacoxae; pronotum wider than long, trapeziform; frontal and humeral angles rounded; anterolateral margins straight; anterior lobe of pronotum with four transverse impressions behind calli; scutellum wider than long; stem and arms equally broad; apex subacute; hemelytra macropterous, extending beyond apex of last abdominal segment; claval and corial veins slightly raised. Parameres. As in figures 7-8.

Measurements. Male holotype. Body length $4.93 \mathrm{~mm}$. Head length $0.64 \mathrm{~mm}$; width across eyes $1.20 \mathrm{~mm}$; interocular distance $0.68 \mathrm{~mm}$; interocellar distance $0.40 \mathrm{~mm}$; 
preocular distance $0.46 \mathrm{~mm}$; length antennal segments: I, $0.32 \mathrm{~mm}$, II, $0.80 \mathrm{~mm}$, III, $0.64 \mathrm{~mm}$, IV, $0.92 \mathrm{~mm}$. Pronotum length $0.92 \mathrm{~mm}$; width across humeral angles $1.44 \mathrm{~mm}$. Scutellum length $0.52 \mathrm{~mm}$, width $0.64 \mathrm{~mm}$.

Female. Habitus and color similar to male holotype. Connexival segments VIII-IX, dorsal abdominal segments VIII-IX and genital plates black.

Measurements. Female paratype. Body length $5.58 \mathrm{~mm}$. Head length $0.66 \mathrm{~mm}$; width across eyes $1.24 \mathrm{~mm}$; interocular distance $0.76 \mathrm{~mm}$; interocellar distance $0.46 \mathrm{~mm}$; preocular distance $0.56 \mathrm{~mm}$; length antennal segments: I, $0.34 \mathrm{~mm}, \mathrm{II}, 0.80 \mathrm{~mm}, \mathrm{III}, 0.64 \mathrm{~mm}, \mathrm{IV}, 0.92 \mathrm{~mm}$. Pronotum length $1.00 \mathrm{~mm}$; width across humeral angles $1.64 \mathrm{~mm}$. Scutellum length $0.53 \mathrm{~mm}$, width $0.75 \mathrm{~mm}$.

Variation. 1, anterolateral margins of pronotum black or with very narrow and diffuse yellow mark at the anterior third. 2, connexival segments black with upper border yellow to castaneous orange. 3 , posterior margin of metapleuron dark castaneous to almost black. 4, abdominal sterna III-VI with or without black longitudinal stripe across midline.

Differential diagnosis. Like $O$. (A.) disseptus (Stål, 1874) and $O$. (A.) lynceus Brailovsky, 1982, with abdominal sterna III-VI shiny orange to red; pronotum with anterolateral margins black, and anterior and posterior margins yellow to white; and costal margin of corium yellowish and clearly narrowing apically. Ochrimnus (Aglaochrimnus) nigrosteolaris sp. nov., is segregated by having the ostiolar peritreme black, and posterior margin of metapleuron dark orange to brown. On the other two species the ostiolar peritreme is yellow and the posterior margin of metapleuron is widely yellow. The parameres of each species (Figures 7-12) are distinct.

Etymology. The species epithet, with the Latin adjective nigra (black), make reference to the diagnostic color of the ostiolar peritreme.

Distribution. Venezuela: Mérida.

\section{Ochrimnus (Aglaochrimnus) rostratum sp. nov. Figures 1, 13-14 \\ http://zoobank.org/F77E76CC-D306-4993-983F- 7E319EB94058}

Type locality. Brazil, Corumba.

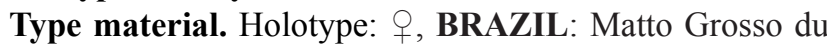
Sul, Corumba, iv (without information) (CMNH). PARATYPE: 1 Oे, BRAZIL: Matto Grosso du Sul, Corumba, iv (without information) (UNAM).

Description. Female (holotype). Dorsal coloration. Head dark reddish brown with pale yellow discoidal spot at vertex; antennal segments I-IV dark reddish brown; ocelli shiny red; eyes dark brown; pronotum black with outer margin of humeral angles and posterior margin yellowish orange; pronotal disk with a short triangular yellowish-orange mark on middle third of posterior margin, with apex extending just behind calli; callus transversely dark reddish brown; scutellum black with apex yellow; clavus and cori- um dark reddish brown with claval commissure, and costal and apical margins yellow; costal margin of corium yellow, narrowing apically; hemelytral membrane with narrow white margin; connexival segments III-VI yellow, and VIIIX black; dorsal abdominal segments III-VI shiny orange and VII-IX black.

Ventral coloration. Head and rostral segments I-IV black; buccula black with outer border with a narrowing white band; prosternum black with anterior border with a narrowing yellow band; mesosternum black with posterior border with a narrowing yellow band; metasternum black; pro- and mesopleura black; metapleuron black, posterior border with a narrowing yellow band; inner border of pro-, meso-, and meta-acetabulae with narrowing yellow band; ostiolar peritreme yellow; legs dark reddish brown; abdominal sternite III shiny orange, laterally black; sterna IV-VI shiny orange with posterior border and lateral margin black; sternite VII and genital plates black; pleural margins of abdominal sterna III-VII yellow.

Structure. Head elongate, non declivent, wider than long; vertex slightly convex; ocelli raised above surface; antennal segment I reaching the apex and not surpassing the tylus; buccula moderately raised; rostrum reaching posterior border of abdominal sternite IV; pronotum wider than long, trapeziform; frontal and humeral angles rounded; anterolateral margins straight; anterior border concave; posterolateral borders and posterior border straight; anterior lobe of pronotal disk with four transverse impressions behind calli; scutellum wider than long; apex subacute; macropterous, extending beyond the apex of last abdominal segment; claval and corial veins slightly raised.

Measurements. Female holotype. Body length 7.57 $\mathrm{mm}$. Head length $1.09 \mathrm{~mm}$; width across eyes $1.33 \mathrm{~mm}$; interocular distance $0.80 \mathrm{~mm}$; interocellar distance $0.56 \mathrm{~mm}$; preocular distance $0.76 \mathrm{~mm}$; length antennal segments: I, $0.44 \mathrm{~mm}$, II, $1.08 \mathrm{~mm}$, III, $0.96 \mathrm{~mm}, \mathrm{IV}, 1.28 \mathrm{~mm}$. Pronotum length $1.24 \mathrm{~mm}$; width across humeral angles $2.16 \mathrm{~mm}$. Scutellum length $0.72 \mathrm{~mm}$, width $0.84 \mathrm{~mm}$.

Male. Habitus and color similar to female holotype. Head dorsally dark castaneous with yellowish discoidal spot at vertex; tylus dark reddish brown; antennal segments I-III (IV broken) dark castaneous; head ventrally pale castaneous orange; fore legs with coxae and trochanters yellow, and femora, tibiae and tarsi dark reddish castaneous; middle and hind legs with coxae dark castaneous, trochanters yellow, femora with basal half yellowish orange and apical half reddish brown, tibiae pale castaneous with basal and apical joint darker and tarsi reddish brown; abdominal sterna III-VI shiny orange and laterally black; sternite VII black; pleural margins III-VII yellow; genital capsule black. Parameres. As in figures 13-14.

Measurements. Male paratype. Body length $6.82 \mathrm{~mm}$. Head length $1.08 \mathrm{~mm}$; width across eyes $1.24 \mathrm{~mm}$; interocular distance $0.76 \mathrm{~mm}$; interocellar distance $0.59 \mathrm{~mm}$; preocular distance $0.78 \mathrm{~mm}$; length antennal segments: I, $0.36 \mathrm{~mm}$, II, $1.08 \mathrm{~mm}$, III, $0.92 \mathrm{~mm}$, IV broken. Pronotum 
length $1.20 \mathrm{~mm}$; width across humeral angles $2.00 \mathrm{~mm}$. Scutellum length $0.64 \mathrm{~mm}$, width $0.87 \mathrm{~mm}$.

Differential diagnosis. Like $O$. (A.) cellus Brailovsky, 1982, O. (A.) disseptus Stål 1874, O. (A.) lynceus Brailovsky, 1982, O. (A.) mirum Brailovsky, 1982, and O. (A.) schizus Brailovsky, 1982, with head black and a yellowish discoidal spot at vertex; scutellum black with apex yellow; clavus and corium black to dark brown with claval commissure, and costal and apical margins of corium yellow; and abdominal sterna III-VI shiny red to shiny orange, laterally black and pleural margins yellow. Ochrimnus (A.) rostratum sp. nov., is clearly separated by having the head conspicuously elongate, not declivent, with the vertex almost flat, and the rostrum exceptionally elongate reaching the posterior border of abdominal sternite IV; antennal segment I reaching apex and not extending beyond the apex of tylus; and buccula black with only the upper border yellow. On the other species the head is shorter, and not elongate, moderately declivent, with vertex convex; rostrum reaching posterior border of metasternum; antennal segment I surpassing the tylus by about $1 / 3$ its length; and buccula entirely yellowish white. The parameres are distinct (Figures 9-14).

Etymology. Named for the conspicuously elongate rostrum.

Distribution. Brazil: Corumba.

Zygocellus gen. nov.

http://zoobank.org/C539E87B-21B4-442A-8FD2062B501D6EE6

Type species. Zygocellus saphisus sp. nov., here designated.

Description. Body moderately elongate, widest across middle of abdomen, length less than $5.00 \mathrm{~mm}$.

Head wider than long across eyes, sloping downward, vertex almost flat; ocelli much closer to eyes than to each other; ocellus small, slightly raised above surface; eyes hemispheric, not protruding, with posterior margin nearly touching frontal angles of pronotum; buccula moderately produced, reaching middle third of eyes; rostrum extending to posterior border of abdominal sternite IV; rostral segment I thickest, elongate, touching anterior margin of prosternum.

Thorax. Pronotum. Wider than long, trapeziform; anterior margin concave; frontal angles obtuse, nearly touching posterior border of eyes; posterior margin straight, with shallow but distinct depression laterally; anterolateral margins obliquely straight; calli indistinct, defined primarily by punctate areas immediately before and behind; callar impressions unbranched, obliquely sinuate, angled towards frontal pronotal angles; median carina obsolete. Propleuron divided into three parts by dorso-ventral impressions; anterior and posterior parts coarsely punctate, median part smooth; meso-, and metapleura with anterior half smooth, and posterior half punctate; posterior border of metapleuron almost straight; osteolar peritreme well developed. Legs.
Unarmed; femora elongate. Scutellum. Wider than long, triangular; median carina T-shaped, with stem and arms clearly exposed and defined; lateral fovea deep. Hemelytra. Macropterous, surpassing apex of abdomen; costal margin emarginate; veins not raised.

Genital capsule. Subcircular in cross section.

Vestiture. Smooth except for punctures immediately before and behind calli, and on pro-, meso-, and metapleuron. Head, pronotum, scutellum, clavus, corium, thorax, and legs almost glabrous; abdominal sterna clothed with short, fine, decumbent, silvery setae.

Female. Unknown.

Differential diagnosis. This new genus is related to Melanopleurus Stål (1874), Melanopleuroides A. Slater and Baranowski (1992), and Zygochrimnus Brailovsky (2018). The general appearance is similar, with eyes not stalked; calli not depressed; pronotum without four transverse impressions behind calli; scutellum not swollen, with a T-shaped carina; pronotal disk almost entirely black to pale brown; and usually small bugs less than $5.00 \mathrm{~mm}$.

Melanopleurus and Zygochrimnus are easily separated by having a distinct pale yellow to yellowish white discoidal spot on vertex, which is absent on the other two genera.

In Melanopleuroides, known only from the Dominican Republic, the head dorsally, pronotum, scutellum, clavus and corium are densely clothed with short semidecumbent hairs; the vertex is convex; the posterior margin of metapleuron is distinctly concave; rostrum shorter, reaching posterior margin of metacoxae; outer margin of hemelytral membrane is black; and pronotal disk, scutellum, and clavus are entirely black. In Zygocellus gen. nov., here described from Brazil, the dorsal surfaces are almost glabrous; the vertex is nearly flat; the posterior margin of metapleuron straight; the rostrum conspicuously longer reaching posterior border of abdominal sternite IV; the outer margin of hemelytral membrane is dark yellow; and the pronotal disk, scutellum, and clavus bicolorous.

Etymology. Named after its similarity in appearance to the genus Zygochrimnus.

\section{Zygocellus saphisus sp. nov.}

Figure 6

http://zoobank.org/BB8566A8-789E-4D8A-BBAED3E572741BF7

Type locality. Bolivia, Chapare.

Type material. Holotype $\widehat{\partial}$, BOLIVIA: Chapare, xi (without additional information) (CMNH).

Description. Male (holotype). Dorsal coloration. Head dark reddish brown to black; tylus and jugum dark castaneous; ocelli pale reddish; eyes dark reddish brown; antennal segments I-IV dark castaneous; pronotum brown, punctures black and anterior lobe across callus orange; scutellum dark brown with apex yellow; clavus with basal half, claval margin bordering scutellum, and claval commissure pale yellowish white; posterior half black; corium mostly black, with anterior angle, apical margin, and apical angle 
yellowish white; claval and corial veins concolorous with surrounding areas; hemelytral membrane brown with outer margin dark yellow; veins concolorous with surrounding areas; connexival segments dark yellow.

Ventral coloration. Head pale brown; buccula yellowish white; antenniferous tubercles and rostral segments I-IV shiny brownish castaneous; pro-, meso-, and metasterna pale brown; propleuron pale brown with wide pale orange stripe at midline; meso-, and metapleuron pale brown; pro, meso-, and meta-acetabulae yellowish white with upper margin pale orange; ostiolar peritreme orange; legs dark castaneous; abdominal sterna III-VI pale yellow except lateral margins of sterna III-IV near pleural margin pale brownish castaneous; sternite VII and genital capsule dark to pale brownish castaneous; pleural abdominal sterna IIIVII yellow.

Female. Unknown.

Measurements. Male holotype. Body length $4.83 \mathrm{~mm}$. Head length $0.66 \mathrm{~mm}$; width across eyes $1.04 \mathrm{~mm}$; interocular distance $0.64 \mathrm{~mm}$; interocellar distance $0.40 \mathrm{~mm}$; preocular distance $0.48 \mathrm{~mm}$; length antennal segments: I, $0.36 \mathrm{~mm}$, II, $0.85 \mathrm{~mm}$, III, $0.67 \mathrm{~mm}, \mathrm{IV}, 0.80 \mathrm{~mm}$. Pronotum length $0.94 \mathrm{~mm}$; width across humeral angles $1.48 \mathrm{~mm}$. Scutellum length $0.50 \mathrm{~mm}$, width $0.68 \mathrm{~mm}$.

Etymology. From the Greek saphis (distinct), referring to the peculiarly delimited color pattern on the pronotum and clavus.

\section{Zygochrimnus morronesus sp. nov.}

Figure 4

http://zoobank.org/7B4117B6-6A16-465E-8A3E-C784B07CAC77

Type locality. Argentina, Neuquen.

Type material. Holotype $\hat{\sigma}$, ARGENTINA: Neuquen, Hwy 60, 9 km W, Hwy 23 E, Mamuil Malal Colen, 890

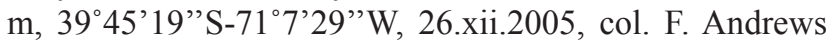
(UCRC).

Description. Male (holotype). Dorsal coloration. Head dark reddish brown, except middle third of tylus, upper border of jugum and discoidal spot on vertex yellow; antennal segments I-IV dark castaneous orange; ocelli translucent; eyes dark reddish; pronotum reddish brown; upper border of anterior lobe dark yellow; humeral angles white; scutellum reddish brown; apex dark yellow; clavus yellowish white with an irregular and elongate reddish-brown spot near middle third; corium reddish brown with apical third yellowish white; costal margin yellowish white, interrupted at middle third by a reddish-brown stripe; hemelytral membrane dark brown with basal angle and outer margin pale white; connexival segments III-VI yellow, VII dark brown; dorsal abdominal segments III-VI yellow, VII dark brown.

Ventral coloration. Head pale brown; buccula white with inner margin pale brown; rostral segments I-II and IV shiny castaneous, III shiny yellow; pro.-, meso- and metasternum pale brown; propleuron pale brown with anterior border white; meso., and metapleura pale brown with anterior margin white; pro.-, meso-, and meta-acetabulae and ostiolar peritreme white; coxae shiny dark castaneous; trochanters yellow; femora dark castaneous; tibiae and tarsi pale castaneous; abdominal sterna III-V dark brownish castaneous; VI-VII paler; pleural margin III dark brownish castaneous; IV-VII yellow, with scattered pink reflections; genital capsule dark brown.

Structure. Moderately robust, ovoid, widest point across middle of abdomen. Head wider than long; vertex almost flat; posterior margin of eyes touching frontal angles of pronotum; rostrum reaching posterior margin of metasternum. Thorax. Pronotum wider than long; frontal angles gently raised; anterolateral margins slightly sinuate; calli indistinct; callar impressions unbranched. Scutellum wider than long; median carina T-shaped; lateral fovea deep. Legs unarmed.

Vestiture. Smooth, except for tiny punctures immediately before and behind calli. Head dorsally, pronotum, scutellum, clavus, corium, legs, and abdominal sterna densely clothed with long, stout, silvery, upright setae; head ventrally and thorax clothed with short fine, decumbent silvery setae.

Female. Unknown.

Measurements. Male holotype. Body length $4.78 \mathrm{~mm}$. Head length $0.64 \mathrm{~mm}$; width across eyes $1.20 \mathrm{~mm}$; interocular distance $0.70 \mathrm{~mm}$; interocellar distance $0.49 \mathrm{~mm}$; preocular distance $0.46 \mathrm{~mm}$; length antennal segments: I, $0.36 \mathrm{~mm}$, II, $0.68 \mathrm{~mm}$, III, $0.52 \mathrm{~mm}$, IV, $0.76 \mathrm{~mm}$. Pronotum length $1.00 \mathrm{~mm}$; width across humeral angles $1.60 \mathrm{~mm}$. Scutellum length $0.56 \mathrm{~mm}$, width $0.74 \mathrm{~mm}$.

Differential diagnosis. Zygochrimnus morronesus sp. nov. (Figure 4) is the second species known in the genus, and like Zygochrimnus henryi Brailovsky, 2018 (Figure 2), the species presents body length shorter than $5 \mathrm{~mm}$; head dorsally with yellow discoidal spot on vertex; posterior margin of eyes touching frontal angles of pronotum; rostrum reaching posterior margin of metasternum; frontal angles gently raised; calli indistinct; callar impression unbranched, obliquely sinuated, angled toward frontal angles; median carina obsolete; legs unarmed; and apical margin of corium yellowish white interrupted at middle third by a reddish-brown stripe. In Zygochrimnus morronesus here described from Argentina, the body is robust and ovoid; the vertex is almost flat; antennal segments I-IV are dark castaneous orange; the trochanters are yellow; and the anterior margin of meso-, and metapleura are white. In Zygochrimnus henryi known from Ecuador and Perú the body is elongate and subovoid; the vertex is convex; antennal segments I-III are pale reddish brown, IV dark orange; the trochanters are dark reddish orange; and the abdominal sterna III-VII are entirely black to dark reddish brown.

Etymology. With great pleasure, I dedicate this interesting species to my friend and colleague Dr. Juan Jose Morrone Lupi, in honor of his seminal contribution on Entomology and biogeography.

Distribution. Argentina: Neuquen. 


\section{ACKNOWLEDGMENTS}

I thank Mick Webb (BMNH), John L. Rawlins (CMNH), Carlos Bordón (IZAV), Christiane Weirauch (UCRC), and Fernando Fernandez (UNDC), for lending specimens and other assistance relevant to this study. Special thanks go to Ernesto Barrera (UNAM) for the photographs, also to Julio Cesar Montero (UNAM) and Diana Martinez Almaguer (UNAM) for the plates design, and to Oscar Federico Francke Ballve (UNAM) for comments on the manuscript.

\section{LITERATURE CITED}

Baranowski, R.M. and J.A. Slater. 2005. The Lygaeidae of the West Indies. University of Florida, IFAS, Florida Agricultural Experiment Station, 402: 1-266.

Brailovsky, H. 1982: Revision del complejo Ochrimnus, con descripción de nuevas especies y nuevos géneros (Hemiptera, Heteroptera, Lygaeidae, Lygaeinae). Folia Entomologica Mexicana, 51: 1-163.

Recibido: 11 febrero 2021

Aceptado: 27 abril 2021
Brailovsky, H. 2018: Zygochrimnus henryi, a new genus and species from South America (Hemiptera, Lygaeoidea, Lygaeidae). ZooKeys, 796: 319-324.

Cervantes Peredo, L. and H. Brailovsky. 2014: Two new endemic species of Lygaeinae from Baja California, Mexico (Hemiptera: Heteroptera: Lygaeidae). Zootaxa, 3861: 591-597.

Dellapé, P.M. and T.J. Henry. 2020. Lygaeoidea Species File. Version 5.0/5.0.

Henry, T.J., P.M. Dellapé and A.S. Paula. 2015: Chapter 16. The big-eyed bugs, chinch bugs, and seed bugs (Lygaeoidea), pp. 459-514. In Panizzi A.R. and J. Grazia (Eds.) TrueBugs (Heteroptera) of the Neotropics. Springer, Dordrecht.

Slater, A. 1992: A genus level revision of Western Hemisphere Lygaeinae (Heteroptera: Lygaeidae) with keys to species. The University of Kansas Science Bulletin, 55: $1-56$.

Slater, A. and R.M. Baranowski. 2001: Melanopleuroides dominicanus, a new Lygaeinae genus and species from the Dominican Republic (Heteroptera: Lygaeidae). Florida Entomologist, 84: 131-132.

Stål, C. 1874: Enumeratio Hemipterorum pt. 4. Kongliga Svenska Vetenskaps-Akademiens Handlingar 12: 1-186. 


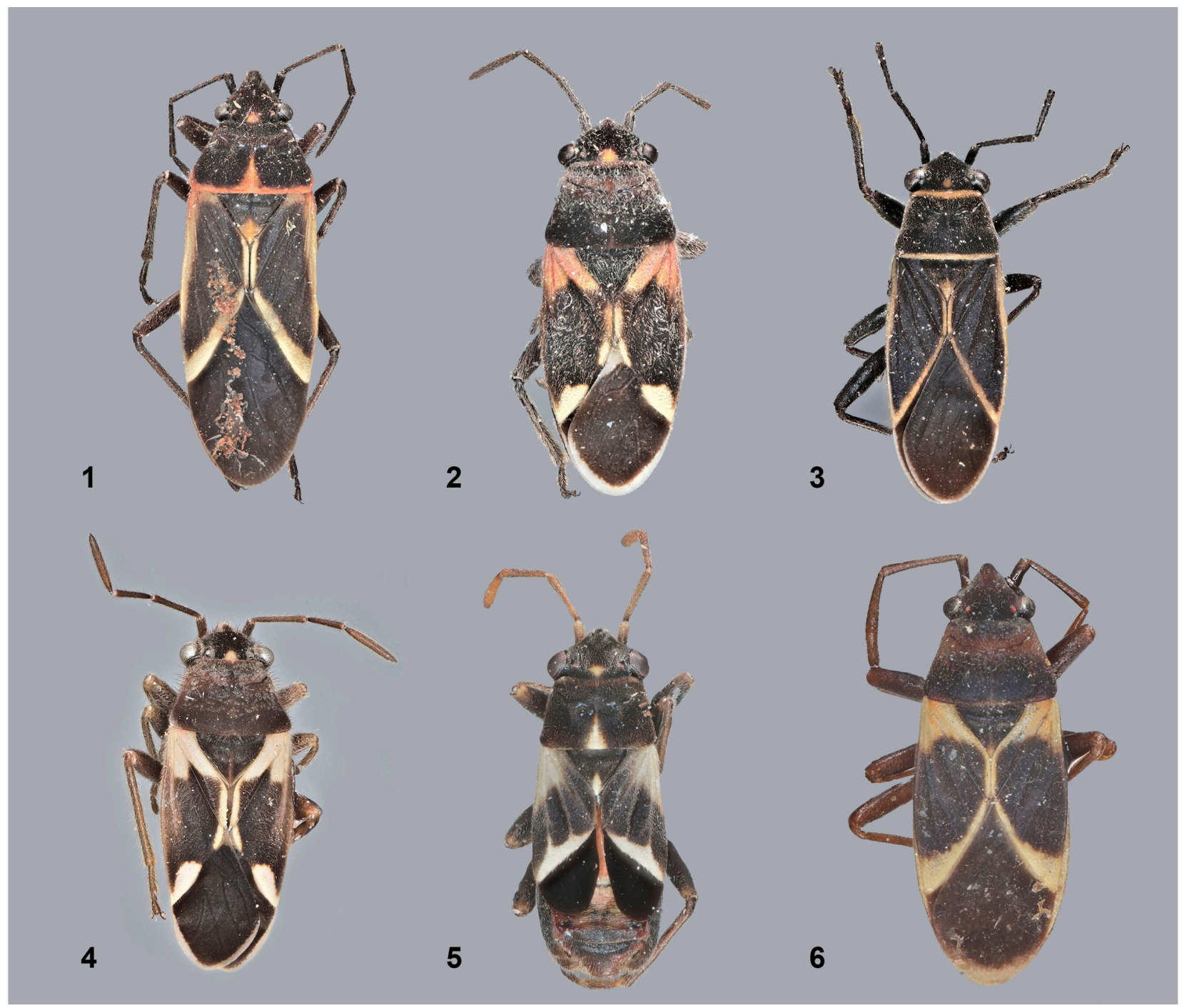

Figures 1-6. Dorsal view. 1, Ochrimnus (Aglaochrimnus) rostratum sp. nov. (female). 2, Zygochrimnus henryi Brailovsky (male). 3, Ochrimnus (Aglaochrimnus) nigrosteolaris sp. nov. (male). 4, Zygochrimnus morronesus sp. nov. (male). 5, Ochrimnus (Orthochrimnus) naevillus sp. nov. (male). 6, Zygocellus saphisus sp. nov. (male). 
7
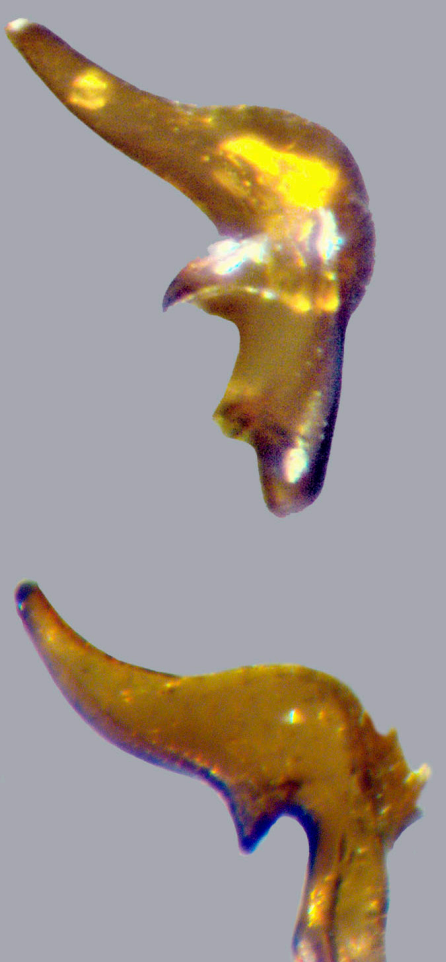

9

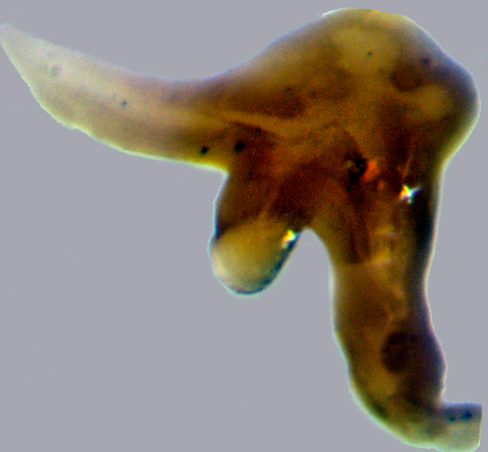

11

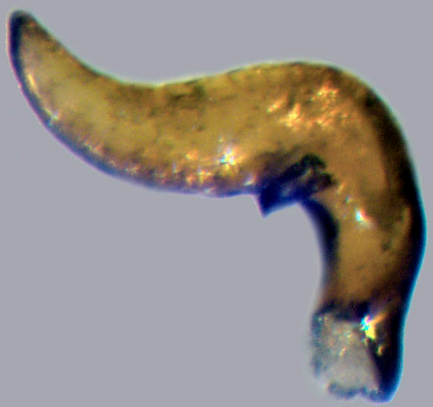

8

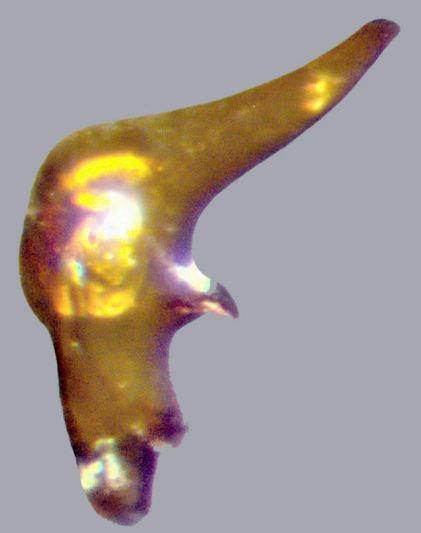

10

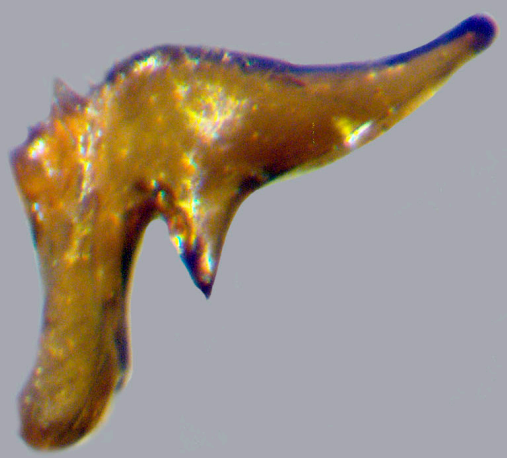

12

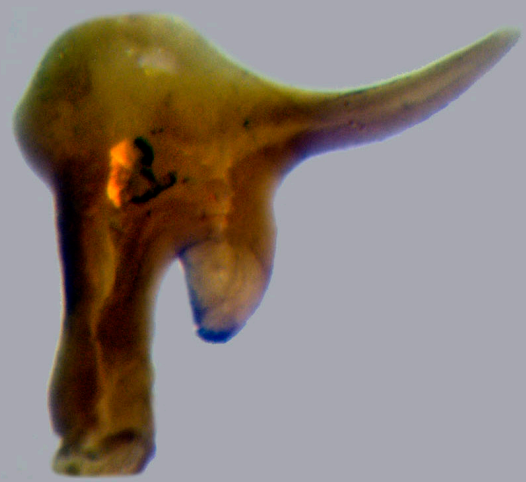

14

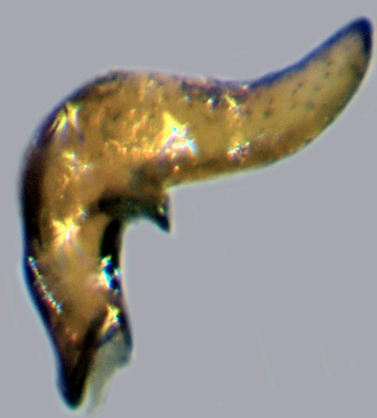

Figures 7-14. Parameres. 7-8, Ochrimnus (Aglaochrimnus) nigrosteolaris sp. nov. 9-10, Ochrimnus (Aglaochrimnus) disseptus Stål. 11-12, Ochrimnus (Aglaochrimnus) lynceus Brailovsky. 13-14, Ochrimnus (Aglaochrimnus) rostratum $\mathbf{s p . ~ n o v . ~}$ 